\title{
Neospora caninum in free-range chickens (Gallus gallus domesticus) from southern Brazil
}

\author{
Neospora caninum em galinhas de vida livre (Gallus gallus domesticus) \\ do sul do Brasil \\ João Pedro Sasse"; Ana Clécia dos Santos Silva'; Priscilla Gomes Carneiro'; Beatriz de Souza Lima Nino'; \\ Fernando Emmanuel Gonçalves Vieira²; Luiz Daniel de Barros (D); João Luis Garcia \\ 'Departamento de Medicina Veterinária Preventiva, Laboratório de Protozoologia Animal, Universidade Estadual de Londrina - UEL, \\ Londrina, PR, Brasil \\ ${ }^{2}$ Laboratório de Parasitologia e Zoologia, Universidade Estadual Norte do Paraná - UENP, Jacarezinho, PR, Brasil
}

How to cite: Sasse JP, Silva ACS, Carneiro PG, Nino BSL, Vieira FEG, de Barros LD, et al. Neospora caninum in free-range chickens (Gallus gallus domesticus) from southern Brazil. Braz J Vet Parasito/ 2020; 29(4): e013620. https://doi.org/10.1590/S1984-29612020107

\begin{abstract}
Neospora caninum is an obligate intracellular parasite that can infect many domestic and wild animals, including birds. These animals are important sources for monitoring of environmental contamination, as they could become infected through sporulated oocysts; however, the real role of birds in the biological cycle of $\mathrm{N}$. caninum remains uncertain. This study aimed to determine the prevalence of anti-N. caninum antibodies, evaluate associated factors, detect the parasite by molecular testing of free-range chickens from Brazil, and evaluate different techniques for its serological diagnosis. Blood samples of 366 chickens from 25 farms were collected for serological assays. The indirect fluorescent antibody test (IFAT) and the indirect enzyme-linked immunosorbent assay (ELISA) were used to detect anti-N. caninum antibodies. Chickens that tested seropositive by IFAT had their brain tissues and a pool of organs (heart, lung, and liver) submitted to PCR for molecular detection of the parasite. Out of 366 chickens, 65 $(17.8 \%)$ and $163(44.6 \%)$ were seropositive by IFAT and ELISA, respectively. Brain tissues $(n=60)$ and the pools of organs ( $n=65$ ) were negative in the PCR. Our results showed a high prevalence of antibodies in free-range chickens and that IFAT is the more sensitive technique for the detection of anti-N. caninum antibodies.
\end{abstract}

Keywords: Free-range chicken, indirect fluorescent antibody test, enzyme-linked immunosorbent assay, polymerase chain reaction.

\begin{abstract}
Resumo
Neospora caninum é um parasita intracelular obrigatório que pode infectar vários animais domésticos e silvestres, incluindo as aves. Esses animais são importantes fontes para o monitoramento da contaminação ambiental, uma vez que eles podem se infectar por meio da ingestão de oocistos. Porém, o real papel das aves no ciclo biológico do $N$. caninum ainda é incerto. Este estudo teve como objetivos determinar a prevalência de anticorpos anti-N. caninum, avaliar fatores associados, detectar o parasita por meio de teste molecular em galinhas de vida livre do Brasil e avaliar diferentes técnicas para o diagnóstico sorológico. Amostras de sangue de 366 galinhas de 25 fazendas foram coletadas para testes sorológicos. A reação de imunofluorescência indireta (RIFI) e o ensaio de imunoabsorção enzimática (ELISA) foram utilizados para detectar anticorpos anti-N. caninum. As amostras de tecidos (cérebro, coração, pulmão e fígado) de galinhas soropositivas na RIFI foram coletadas e submetidas à PCR para detecção molecular do parasita. Das 366 galinhas, 65 (17,8\%) e $163(44,6 \%)$ foram soropositivas pela RIFI e ELISA, respectivamente. Nenhuma amostra foi positiva na PCR. Esses resultados demonstram uma elevada prevalência de anticorpos em galinhas de vida livre e que a RIFI é uma técnica mais sensível para a detecção de anticorpos anti-N. caninum.
\end{abstract}

Palavras-chave: Galinhas de vida livre, imunofluorescência indireta, ensaio de imunoabsorção enzimática, reação em cadeia da polimerase.

Received June 09, 2020. Accepted October 5, 2020

*Corresponding author: Luiz Daniel de Barros. E-mail: daniel_vetuel@hotmail.com

This is an Open Access article distributed under the terms of the Creative Commons Attribution License, which permits unrestricted use, distribution, and reproduction in any medium, provided the original work is properly cited. 


\section{Introduction}

Neospora caninum is an Apicomplexa protozoan, of worldwide distribution, capable of infecting many domestic and wild animals, including birds (Dubey \& Schares, 2011; Romero et al., 2016). The disease causes abortion in cattle and has considerable importance in cattle production, resulting in high economic losses worldwide (Reichel et al., 2013). In dogs, the disease is usually asymptomatic, although clinical manifestations that include muscular and neurological disorders have been described in young dogs (Silva \& Machado, 2016).

In birds, serological evidence of $N$. caninum has been described in different species, including domestic and wild birds (Costa et al., 2008; Mineo et al., 2009; Gondim et al., 2010; Darwich et al., 2012; Salant et al., 2015; De Barros et al., 2017; Konell et al., 2019). A recent review showed that the seroprevalence in chickens (Gallus gallus domesticus) ranged from $7.2 \%$ to $83.6 \%$ according to the region (De Barros et al., 2018). The eating habits of birds increases their exposure to these pathogens, and since birds may be predated by dogs, chickens could contribute to the epidemiology of the parasite. Moreover, previous studies have reported a positive correlation between the presence of birds on the farm and increased reproductive problems in cattle that could be related to $N$. caninum (Bartels et al., 1999; Otranto et al., 2003).

Since the role of birds in the epidemiology of neosporosis is not fully understood, the present study aimed to detect N. caninum in free-range chickens from Brazil, and evaluate different techniques for its serological diagnosis.

\section{Material and Methods}

\section{Sampling and animals}

Tissue (heart, brain, lung, and liver) and blood samples of 366 free-range chickens were collected between 2012 and 2014 from 25 farms of Paraná state, south Brazil (Figure 1). For sample size calculation, we assumed a prevalence of $50 \%$, a confidence level of $95 \%$, and efficacy $5 \%$ by the Epi Info version 3.5.4. An epidemiological questionnaire was applied for each farmer to determine possible factors associated with exposure to $N$. caninum in chickens. All procedures involving animals were approved by the Ethics Committee of the State University of Londrina (protocol number 64/10).

\section{Indirect fluorescent antibody test (IFAT)}

Serum samples from chickens were tested by IFAT according to the methodology described previously (Conrad et al., 1993). Tachyzoites of NC-1 strain of N. caninum were used as antigen, while anti-chicken IgY conjugate labeled with fluorescein isothiocyanate (FITC) (F8888 - Sigma-Aldrich, USA) was used as a secondary antibody. Serum samples from chickens experimentally inoculated with $N$. caninum (NC-1 strain) and non-infected chickens were

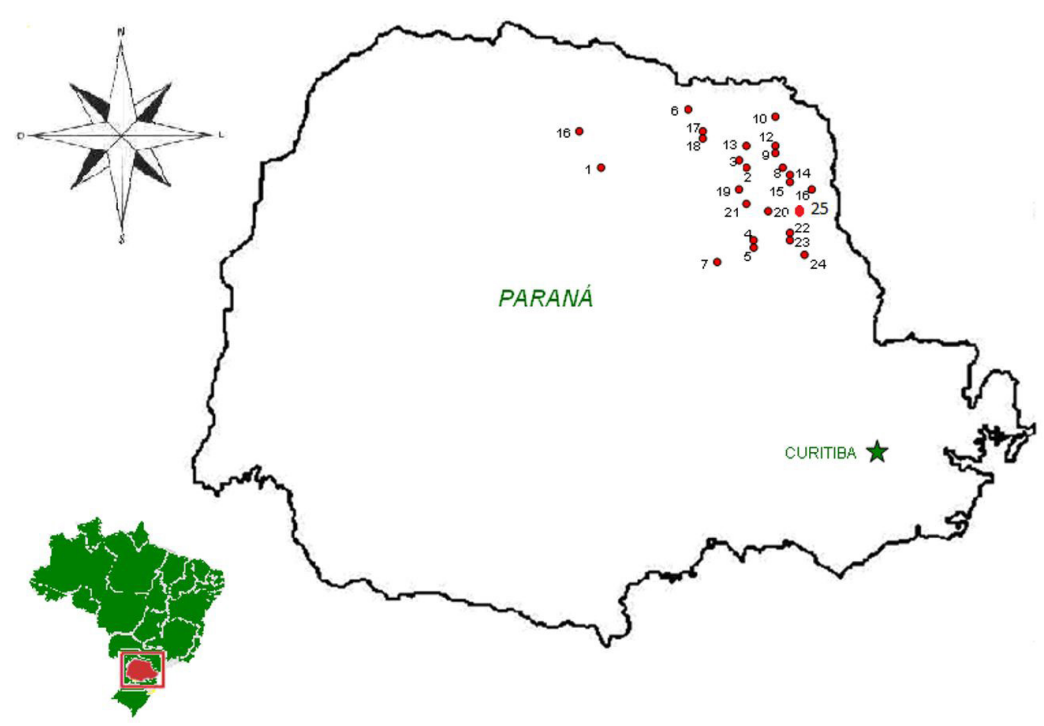

Figure 1. Location of free-range farms in Paraná state, Brazil, selected for collection of the animals used in the present study. 
used as the positive and negative control, respectively. Samples that showed fluorescence over the total contour of the tachyzoite were considered positive. Since there are is not an established cut-off for chickens, we used the cut-off $\geq 16$ to improve the sensitivity of the test.

\section{Enzyme-linked immunosorbent assay (ELISA)}

The ELISA was performed according to the methodology described previously (Paré et al., 1995) with few modifications. Tachyzoites of NC-1 strain grown in Vero cells were used to produce the total antigen. The tachyzoites obtained were passed through $27 \mathrm{G}$ needles, centrifuged at 10,000 g for $10 \mathrm{~min}$, and the pellet was mixed with ceramic beads via vortexing three times for $10 \mathrm{~min}$ each. The resultant solution was centrifuged under the same conditions as described before, and the pellet was discarded. Finally, the protein concentration was quantified by a commercial kit (Pierce ${ }^{\mathrm{TM}}$ BCA, Thermo Fisher Scientific, USA), and the antigen was stored at $-20^{\circ} \mathrm{C}$ until further analysis.

Flat-bottom 96-well polystyrene microtitration plates (Nunc-Immuno Plate Maxisorp, Denmark) were coated with $100 \mu \mathrm{l}$ of crude antigen $(2.5 \mu \mathrm{g} / \mathrm{ml})$ diluted in $0.1 \mathrm{M}$ carbonate buffer $(\mathrm{pH} 9.6)$ and incubated at $4^{\circ} \mathrm{C}$ overnight. After incubation, the plates were washed three times with PBS-Tween $20(50 \mathrm{mM}$ Tris, $100 \mathrm{mM} \mathrm{NaCl}$, and 0.05\% Tween 20), blocked with carbonate buffer plus $8 \%$ nonfat dry milk and incubated at $37^{\circ} \mathrm{C}$ for one hour. Serum samples were diluted 1:100 in PBS-Tween $20 \%$ plus 5\% nonfat dry milk, and $100 \mu$ l of this mixture were added in duplicate into the microplates and incubated for one hour at $37^{\circ} \mathrm{C}$. After another washing cycle, $100 \mu$ l peroxidaselabeled anti-chicken IgY antibody (A9046; Sigma-Aldrich, USA) diluted in PBS-Tween 20\% plus 5\% nonfat dry milk was added in each well, followed by incubation for one hour at $37^{\circ} \mathrm{C}$.

The plates were washed three times, and the peroxidase activity was revealed by adding $100 \mu l$ of tetramethylbenzidine solution (TMB Single Solution; Thermo Fisher Scientific, USA). Then, $50 \mu$ of hydrochloric acid $(1 \mathrm{~N})$ was used to stop the reaction, and the optical density (OD) was read at $450 \mathrm{~nm}$ through a microplate reader (iMark Microplate Absorbance Reader, Bio-Rad, USA). Serum samples from chickens experimentally inoculated with N. caninum (NC-1 strain) (positive control) and non-infected chickens (negative control) were added to all plates. The OD was corrected to control plate-to-plate variation, and the cut-off was calculated by the OD mean of the negative controls plus two times the standard deviation (Garcia et al., 2006b). The corrected OD were grouped into nine levels, where each subsequent level was determined by an increment of 35\% (Machado et al., 1997).

\section{Enzymatic digestion}

Pooled organs (10 g of each tissue, including heart, lung, and liver) were digested as previously described (Dubey, 1998). Briefly, the organs were crushed in saline solution and added to artificial digestive fluid $(0.78 \mathrm{~g}$ pepsin, $0.5 \mathrm{~g} \mathrm{NaCl}, 0.7 \mathrm{ml} \mathrm{HCl}$ and $150 \mathrm{ml}$ of distilled water) for one hour at $37^{\circ} \mathrm{C}$. The product of digestion was filtered and centrifuged at 1,200 g for $10 \mathrm{~min}$. The supernatant was discarded, and the pellet neutralized with a sodium bicarbonate solution 1.2\%. The solution was resuspended in physiological solution and centrifuged again. Then the supernatant was discarded, the solution was resuspended in $1 \mathrm{ml}$, with $1000 \mathrm{Ul}$ of penicillin and $100 \mu \mathrm{g}$ of streptomycin per $\mathrm{ml}$ added and stored $a t-20^{\circ} \mathrm{C}$ until molecular analysis.

\section{DNA extraction}

Animals considered positive by IFAT had their tissue samples submitted to polymerase chain reaction (PCR). Samples of 60 brains ( $25 \mathrm{mg}$ ) and 65 pools of organs (heart, lung, and liver) ( $300 \mu$ l of enzymatic digestion) were used for DNA extraction. The samples were homogenized and transferred to microtubes with an equal volume of extraction buffer ( $200 \mathrm{mM} \mathrm{NaCl}, 20 \mathrm{mM}$ Tris, $50 \mathrm{mM}$ EDTA, proteinase $\mathrm{K} 1 \mathrm{mg} / \mathrm{ml}$ and 2\% SDS), followed by incubation at $56^{\circ} \mathrm{C}$ for one hour. Then, with buffered phenol (300 $\left.\mu \mathrm{l}\right)$ added, it was centrifuged at 13,000 g for $5 \mathrm{~min}$. The supernatant was transferred for another microtube, and with phenol:chloroform:isoamyl alcohol added, it was centrifuged at 13,000 g for 5 min (Garcia et al., 2006a). Then, DNA was precipitated by sodium acetate and ethanol (Sambrook et al., 1989).

\section{PCR}

For the molecular detection of $N$. caninum, a conventional PCR, targeting the Nc5 gene, was performed using the primers Np6 plus (5'-CTCGCCAGTCAACCTACGTCTTCT-3') and Np21 plus (5'-GGGTGTGCGTCCAATCCTGTAAC-3'), 
which amplify a fragment of $337 \mathrm{bp}$ (Hughes et al., 2006). The reaction was performed in $25 \mu \mathrm{l}$ using $100 \mathrm{ng} / \mu \mathrm{l}$ of DNA, $25 \mathrm{mM} \mathrm{MgCl} 2,200 \mu \mathrm{M}$ dNTP (Thermo Fisher Scientific, USA), $1 \mu \mathrm{M}$ of each primer, 1x PCR buffer (20 mM Tris- $\mathrm{HCl}, 50 \mathrm{mM} \mathrm{KCl}, \mathrm{pH}$ 8.4) $1.25 \mathrm{U}$ of Taq-DNA polymerase (Thermo Fisher Scientific, USA) and ultrapure sterile $\mathrm{H}_{2} \mathrm{O}$. The thermocycler program was run in appliance TC-512 (Techne, USA) according to the program: $95^{\circ} \mathrm{C}$ for 5 min for initial denaturation, $35 \mathrm{cycles}$ of $95^{\circ} \mathrm{C}$ for $30 \mathrm{sec}$ for denaturation, $63^{\circ} \mathrm{C}$ for $30 \mathrm{sec}$ for annealing, and $72^{\circ} \mathrm{C}$ for $1 \mathrm{~min}$ for the extension. A final extension at $72^{\circ} \mathrm{C}$ for $5 \mathrm{~min}$ was included. Positive and negative controls were added in all reactions. PCR products were submitted to electrophoresis in agarose gel $1.5 \%$ stained with Sybr ${ }^{\circledR}$ Safe DNA Gel Stain (Thermo Fisher Scientific, USA), visualized and photo-documented under UV (L - PIX EX, Loccus Biotechnology, Brazil).

\section{Statistical analysis}

The kappa coefficient was used to evaluate the agreement between the serological techniques, and the interpretation was performed as previously described (Landis \& Koch, 1977). Sensitivity and specificity were calculated using IFAT as the gold standard (Casartelli-Alves et al., 2014). All the variables were analyzed by chisquare test or Fisher's exact test using a computer software (GraphPad Prism, v.6.0), and p-values $\leq 0.05$ were considered significant.

\section{Results}

Out of 366 serum samples, 65 (17.8\%) were positive by IFAT (Table 1), with the following titers: 16 (86.2\%), $64(12.3 \%)$ and 256 (1.5\%). The occurrence of anti-N. caninum antibodies on each farm ranged from $7 \%$ to $62 \%$, while $72 \%$ (18/25) of the visited farms had at least one positive animal. According to the ELISA test, $163(44.6 \%)$ samples were positive, with the most frequent OD level among the positive samples at level four (Table 2). A

Table 1. Results of serological tests (IFAT and ELISA) for the detection of Neospora caninum in free-range chickens from northern Paraná state, Brazil.

\begin{tabular}{cccccccccc}
\hline & & \multicolumn{3}{c}{ IFAT } & & & & \\
\cline { 3 - 5 } & & Sositive & Negative & Total & & SP (\%) & PPV (\%) & NPV (\%) & Kappa \\
\hline \multirow{2}{*}{ ELISA } & Positive & 32 & 131 & 163 & & & & \\
& Negative & 33 & 170 & 203 & 49.23 & 56.48 & 19.63 & 83.74 & 0.036 \\
& Total & 65 & 301 & 366 & & & \\
\hline
\end{tabular}

SE: sensitivity; SP: specificity; PPV: positive predictive value; NPV: negative predictive value.

Table 2. Classification of positive animals for Neospora caninum in ELISA at different levels of optical density increasing by increments of $35 \%$.

\begin{tabular}{lllll}
\hline & ELISA Level & & Total & \% \\
\hline $\mathbf{0}$ & 0.00 & 0.274 & 203 & 55.5 \\
$\mathbf{1}$ & 0.275 & 0.371 & 16 & 4.4 \\
$\mathbf{2}$ & 0.372 & 0.502 & 20 & 5.5 \\
$\mathbf{3}$ & 0.503 & 0.679 & 28 & 7.7 \\
$\mathbf{4}$ & 0.68 & 0.918 & 31 & 8.5 \\
$\mathbf{5}$ & 0.919 & 1.241 & 26 & 7.1 \\
$\mathbf{6}$ & 1.242 & 1.677 & 14 & 3.8 \\
$\mathbf{7}$ & 1.678 & 2.265 & 13 & 3.5 \\
$\mathbf{8}$ & 2.266 & 3.059 & 6 & 1.6 \\
$\mathbf{9}$ & & & 9 & 2.5 \\
\hline
\end{tabular}


comparison between the serological techniques showed that ELISA had lower sensitivity and specificity than IFAT, presenting $49 \%$ and $56 \%$, respectively. The kappa coefficient of 0.036 demonstrates a slight agreement between the techniques. Factors associated with exposure to N. caninum in chickens were slaughter above 90 days $(p=0.02)$, contact with animal wastes $(p=0.05)$, and chickens raised free all-day $(p=0.005)$ (Table 3$)$. Through PCR, no samples were considered positive.

Table 3. Variables associated with Neospora caninum serum positive at IFAT in free-range chickens.

\begin{tabular}{|c|c|c|c|c|c|}
\hline \multicolumn{2}{|l|}{ Variables } & \multicolumn{2}{|c|}{ IFAT } & \multirow{3}{*}{$\begin{array}{c}\text { Total } \\
331\end{array}$} & \multirow{3}{*}{$\begin{array}{r}\text { p-value } \\
0.89\end{array}$} \\
\hline & & \multirow{2}{*}{$\begin{array}{c}\text { Positive } \\
58\end{array}$} & \multirow{2}{*}{$\begin{array}{c}\text { Negative } \\
273\end{array}$} & & \\
\hline Presence of dog & Yes & & & & \\
\hline & No & 7 & 28 & 35 & \\
\hline Slaughter above 90 days & Yes & 65 & 274 & 339 & 0.02 \\
\hline & No & 0 & 27 & 27 & \\
\hline Contact with animal wastes & Yes & 25 & 77 & 102 & 0.05 \\
\hline & No & 40 & 224 & 264 & \\
\hline Chickens raised near the forest & Yes & 24 & 94 & 118 & 0.45 \\
\hline & No & 41 & 207 & 248 & \\
\hline Chickens raised free all-day & Yes & 20 & 46 & 66 & 0.005 \\
\hline & No & 45 & 255 & 300 & \\
\hline Water protection & Yes & 60 & 281 & 341 & 0.97 \\
\hline & No & 5 & 20 & 25 & \\
\hline
\end{tabular}

\section{Discussion}

We observed that $17.8 \%$ of free-range chickens from Paraná State from Brazil were seropositive for N. caninum, demonstrating that the parasite is circulating in this region, and chickens are exposed to parasitic stages. Previous studies on free-range chickens in Brazil have also described a similar prevalence by IFAT, in Bahia with $17-23.5 \%$ of seropositivity (Costa et al., 2008; Gonçalves et al., 2012), 36.5\% in Rio Grande do Sul (Camillo et al., 2015), and 20\% in São Paulo (Martins et al., 2011). In other countries, the seroprevalence ranged from $23.1 \%$ to $41.5 \%$ (Martins et al., 2011; Feng et al., 2016; Rocchigiani et al., 2017). A similar prevalence was detected in waterfowl birds (17.5\%, 32/182) from Italy, indicating that, as these bird species feed directly on the ground, they have a higher seroprevalence (Nardoni et al., 2019). However, in an urban park from Brazil, only one goose (Anser sp.) (out of 149) was found to be seropositive to $N$. caninum, suggesting that this seroprevalence may be due to a low seroconversion rate or a different type of feed in this species (Konell et al., 2019).

Based on the variable analysis, slaughter above 90 days was a variable associated with exposure to $\mathrm{N}$. caninum in chickens. This result indicates that chickens more than 90 days of age have a higher chance of infection due to longer lifespan; however, a previous study showed no significant association between the N. caninum infection and age of chickens (Feng et al., 2016). Chickens that have contact with animal wastes and raised free all-day were also associated with infection. We suggest that these variables contribute to a higher exposition to the parasitic stages present in the environment since outdoor chickens have higher seropositivity (Costa et al., 2008). The presence of dogs on the farm showed no significant association with seropositivity in chickens; however, the presence of wild canids could contribute to the epidemiology of neosporosis (Melendez et al., 2020).

In the present study, we evaluated the ELISA technique using the total antigen; however, it showed a low sensitivity and specificity. Additionally, the Kappa coefficient showed a slight agreement with IFAT and ELISA, which makes this technique not appropriated for the screening test in epidemiological studies in chickens since cross-reaction with apicomplexan parasites may be present (Gondim et al., 2017). The protein disulfide isomerase (PDI), heat-shock protein (HSP70), and ribosomal proteins (RP1) have been identified as cross-reactive antigens and could be related to the low specificity of the serological test (Liao et al., 2005; Zhang et al., 2011). An ELISA using the surface antigen 1 of $N$. caninum (NcSAG1t) was tested in serum from chickens, and was a good option for serological diagnosis 
of neosporosis in animals since the use of species-specific recombinant proteins avoids cross-reaction (Ibrahim, 2013; Gondim et al., 2017). An agglutination test (N-MAT) showed high sensitivity and specificity for naturally and experimentally infected chickens and could be an alternative tool (Sayari et al., 2016).

According to molecular analyses, no samples were positive. In chickens from China, no positive samples have been observed by molecular analyses in myocardium digestion liquids ( $n=25)$ (Feng et al., 2016). However, the presence of $N$. caninum DNA in chickens was first reported in the brain of six animals, confirming that chickens are natural intermediate hosts of the parasite (Costa et al., 2008). In wild birds that tested seropositive with a low titer of the antibody, a high rate of positive PCR samples was detected, indicating that these birds could also be involved in the epidemiology of $N$. caninum (Nardoni et al., 2019). DNA of $N$. caninum was also detected in brain and heart tissues from wild waterfowl from Italy, showing that these animals can become infected and could contribute to the spread of the parasite. (Rocchigiani et al., 2017).

Animals experimentally infected with tachyzoites and oocysts of two different strains of $N$. caninum yielded negative results at PCR (Oliveira et al., 2018); however, this resistance to chronic infection could be related to the strain of parasite as the parasite had a low capacity for multiplication at temperatures above $39^{\circ} \mathrm{C}$ to $41.5^{\circ} \mathrm{C}$ (Rezende-Gondim et al., 2017). Since we could not detect positive samples by PCR, we suggested that chickens were infected by a low dose of parasites, or they are resistant to chronic infection, being the tissue cysts eliminated due to high corporal temperature of free-range chickens. Moreover, previous studies have demonstrated that chickens present a transient $N$. caninum infection, being seropositive without the establishment of infection (Furuta et al., 2007; Munhoz et al., 2014).

\section{Conclusions}

Our results showed that $N$. caninum is circulating among free-range chickens on the studied farms; however, the importance of these animals on the epidemiology of neosporosis should be elucidated. The ELISA demonstrated a slight agreement with IFAT, being the IFAT a more appropriate technique for epidemiological studies.

\section{References}

Bartels CJM, Wouda W, Schukken YH. Risk factors for Neospora caninum-associated abortion storms in dairy herds in The Netherlands (1995 to 1997). Theriogenology 1999; 52(2): 247-257. http://dx.doi.org/10.1016/S0093-691X(99)00126-0. PMid:10734392.

Camillo G, Cadore GC, Ferreira MST, Braünig P, Maciel JF, Pivoto FL, et al. Toxoplasma gondii and Neospora caninum antibodies in backyard chickens in Rio Grande do Sul, Brazil. Rev Bras Cienc Avic 2015; 17(2): 263-265. http://dx.doi.org/10.1590/1516$635 \times 1702263-265$.

Casartelli-Alves L, Boechat VC, Macedo-Couto R, Ferreira LC, Nicolau JL, Neves LB, et al. Sensitivity and specificity of serological tests, histopathology and immunohistochemistry for detection of Toxoplasma gondii infection in domestic chickens. Vet Parasitol 2014; 204(3-4): 346-351. http://dx.doi.org/10.1016/j.vetpar.2014.05.039. PMid:24953750.

Conrad PA, Sverlow K, Anderson M, Rowe J, BonDurant R, Tuter G, et al. Detection of serum antibody responses in cattle with natural or experimental Neospora infections.J Vet Diagn Invest 1993; 5(4): 572-578. http://dx.doi.org/10.1177/104063879300500412. PMid:8286457.

Costa KS, Santos SL, Uzêda RS, Pinheiro AM, Almeida MAO, Araújo FR, et al. Chickens (Gallus domesticus) are natural intermediate hosts of Neospora caninum. Int J Parasitol 2008; 38(2): 157-159. http://dx.doi.org/10.1016/j.jppara.2007.10.008. PMid:18054356.

Darwich L, Cabezón O, Echeverria I, Pabón M, Marco I, Molina-López R, et al. Presence of Toxoplasma gondii and Neospora caninum DNA in the brain of wild birds. Vet Parasito/ 2012; 183(3-4): 377-381. http://dx.doi.org/10.1016/j.vetpar.2011.07.024. PMid:21831525.

de Barros LD, Miura AC, Minutti AF, Vidotto O, Garcia JL. Neospora caninum in birds: a review. Parasitol Int 2018; 67(4): 397-402. http://dx.doi.org/10.1016/j.parint.2018.03.009. PMid:29614327.

de Barros LD, Taroda A, Martins TA, Miura AC, De Seixas M, Sammi AS, et al. Survey of Neospora caninum in eared doves (Zenaida auriculata) in Southern Brazil. Acta Trop 2017; 174: 132-135. http://dx.doi.org/10.1016/j.actatropica.2017.07.007. PMid:28716354.

Dubey JP, Schares G. Neosporosis in animals-The last five years. Vet Parasitol 2011; 180(1-2): 90-108. http://dx.doi.org/10.1016/j. vetpar.2011.05.031. PMid:21704458.

Dubey JP. Refinement of pepsin digestion method for isolation of Toxoplasma gondii from infected tissues. Vet Parasitol 1998; 74(1): 75-77. http://dx.doi.org/10.1016/S0304-4017(97)00135-0. PMid:9493311. 
Feng Y, Lu Y, Wang Y, Liu J, Zhang L, Yang Y. Toxoplasma gondii and Neospora caninum in Free-Range Chickens in Henan Province of China. BioMed Res Int 2016; 2016: 8290536. http://dx.doi.org/10.1155/2016/8290536. PMid:27274992.

Furuta PI, Mineo TW, Carrasco AO, Godoy GS, Pinto AA, Machado RZ. Neospora caninum infection in birds: experimental infections in chicken and embryonated eggs. Parasitology 2007; 134(Pt 14): 1931-1939. http://dx.doi.org/10.1017/S0031182007003344. PMid:17686190.

Garcia JL, Gennari SM, Machado RZ, Navarro IT. Toxoplasma gondii: detection by mouse bioassay, histopathology, and polymerase chain reaction in tissues from experimentally infected pigs. Exp Parasitol 2006a; 113(4): 267-271. http://dx.doi.org/10.1016/j. exppara.2006.02.001. PMid:16545804.

Garcia JL, Navarro IT, Vidotto O, Gennari SM, Machado RZ, da Luz Pereira AB, et al. Toxoplasma gondii: comparison of a rhoptryELISA with IFAT and MAT for antibody detection in sera of experimentally infected pigs. Exp Parasitol 2006b; 113(2): 100-105. http://dx.doi.org/10.1016/j.exppara.2005.12.011. PMid:16458299.

Gonçalves IN, Uzêda RS, Lacerda GA, Moreira RRN, Araújo FR, Oliveira RHM, et al. Molecular frequency and isolation of cystforming coccidia from free ranging chickens in Bahia State, Brazil. Vet Parasito/ 2012; 190(1-2): 74-79. http://dx.doi.org/10.1016/j. vetpar.2012.05.007. PMid:22673105.

Gondim LFP, Mineo JR, Schares G. Importance of serological cross-reactivity among Toxoplasma gondii, Hammondia spp., Neospora spp., Sarcocystis spp. and Besnoitia besnoiti. Parasitology 2017; 144(7): 851-868. http://dx.doi.org/10.1017/S0031182017000063. PMid:28241894.

Gondim LSQ, Abe-Sandes K, Uzêda RS, Silva MSA, Santos SL, Mota RA, et al. Toxoplasma gondii and Neospora caninum in sparrows (Passer domesticus) in the Northeast of Brazil. Vet Parasito/ 2010; 168(1-2): 121-124. http://dx.doi.org/10.1016/j.vetpar.2009.09.055. PMid:19879051.

Hughes JM, Williams RH, Morley EK, Cook DAN, Terry RS, Murphy RG, et al. The prevalence of Neospora caninum and co-infection with Toxoplasma gondii by PCR analysis in naturally occurring mammal populations. Parasitology 2006; 132(Pt 1): 29-36. http:// dx.doi.org/10.1017/S0031182005008784. PMid:16393351.

Ibrahim HM. Seroprevalence of Neospora caninum antibodies in chicken samples from Delta Egypt using a recombinant NcSAG1 protein-based ELISA. Egypt J Immunol 2013; 20(1): 29-37. PMid:23888555.

Konell AL, Sato AP, Stival M, Malaguini NP, Anjos A, Ferreira RF, et al. Serosurvey of Toxoplasma gondii, Sarcocystis sp. and Neospora caninum in geese (Anser sp.) from urban parks and captivity. Rev Bras Parasitol Vet 2019; 28(2): 221-228. http://dx.doi.org/10.1590/ s1984-29612019042. PMid:31271639.

Landis JR, Koch GG. The measurement of observer agreement for categorical data. Biometrics 1977; 33(1): 159-174. http://dx.doi. org/10.2307/2529310. PMid:843571.

Liao M, Xuan X, Huang X, Shirafuji H, Fukumoto S, Hirata H, et al. Identification and characterization of cross-reactive antigens from Neospora caninum and Toxoplasma gondii. Parasitology 2005; 130(Pt 5): 481-488. http://dx.doi.org/10.1017/S0031182004006948. PMid:15991490.

Machado RZ, Montassier HJ, Pinto AA, Lemos EG, Machado MRF, Valadão IFF, et al. An enzyme-linked immunosorbent assay (ELISA) for the detection of antibodies against Babesia bovis in cattle. Vet Parasito/ 1997; 71(1): 17-26. http://dx.doi.org/10.1016/ S0304-4017(97)00003-4. PMid:9231985.

Martins J, Kwok OCH, Dubey JP. Seroprevalence of Neospora caninum in free-range chickens (Gallus domesticus) from the Americas. Vet Parasitol 2011; 182(2-4): 349-351. http://dx.doi.org/10.1016/j.vetpar.2011.05.023. PMid:21676546.

Melendez P, Ilha M, Woldemeskel M, Graham J, Coarsey M, Baughman D, et al. An outbreak of Neospora caninum abortion in a dairy herd from the State of Georgia, United States. Vet Med Sci 2020: 1-10. https://doi.org/10.1002/vms3.346.

Mineo TW, Carrasco AOT, Marciano JA, Werther K, Pinto AA, Machado RZ. Pigeons (Columba livia) are a suitable experimental model for Neospora caninum infection in birds. Vet Parasito/ 2009; 159(2): 149-153. http://dx.doi.org/10.1016/j.vetpar.2008.10.024. PMid:19027237.

Munhoz AD, Amaral TF, Gonçalves LR, Moraes VMB, Machado RZ. Gallus gallus domesticus are resistant to infection with Neospora caninum tachyzoites of the NC-1 strain. Vet Parasitol 2014; 206(3-4): 123-128. http://dx.doi.org/10.1016/j.vetpar.2014.10.009. PMid:25468016.

Nardoni S, Poli A, Varvaro I, Rocchigiani G, Ceccherelli R, Mancianti F. Detection of Neospora caninum DNA in wild birds from Italy. Pathogens 2019; 8(4): 202. http://dx.doi.org/10.3390/pathogens8040202. PMid:31652735.

Oliveira S, Aizawa J, Soares HS, Chiebao DP, Castro MB, Hora AS, et al. Experimental Neospora caninum infection in chickens (Gallus gallus domesticus) with oocysts and tachyzoites of two recent isolates reveals resistance to infection. Int J Parasitol 2018; 48(2): 117-123. http://dx.doi.org/10.1016/j.jpara.2017.07.004. PMid:28903025. 
Otranto D, Llazari A, Testini G, Traversa D, Frangipane di Regalbono A, Badan M, et al. Seroprevalence and associated risk factors of neosporosis in beef and dairy cattle in Italy. Vet Parasito/ 2003; 118(1-2): 7-18. http://dx.doi.org/10.1016/j.vetpar.2003.10.008. PMid:14651870.

Paré J, Hietala SK, Thurmond MC. An enzyme-linked immunosorbent assay (ELISA) for serological diagnosis of Neospora sp. infection in cattle. J Vet Diagn Invest 1995; 7(3): 352-359. http://dx.doi.org/10.1177/104063879500700310. PMid:7578451.

Reichel MP, Alejandra Ayanegui-Alcérreca M, Gondim LFP, Ellis JT. What is the global economic impact of Neospora caninum in cattle - The billion dollar question. Int J Parasito/ 2013; 43(2): 133-142. http://dx.doi.org/10.1016/j.jpara.2012.10.022. PMid:23246675.

Rezende-Gondim MM, Da Silva AV, Schares G, Gondim LFP. In contrast to Toxoplasma gondii, Neospora caninum tachyzoites did not sustain multiplication in vitro at increased incubation temperatures. Vet Parasito/ 2017; 234: 19-24. https://doi.org/10.1016/j. vetpar.2016.12.013.

Rocchigiani G, Poli A, Nardoni S, Papini R, Mancianti F. Neospora caninum in wild waterfowl: occurrence of parasite DNA and Low antibody titers. J Parasitol 2017; 103(1): 142-145. http://dx.doi.org/10.1645/16-34. PMid:27805842.

Romero DG, Sánchez GFD, Morales SE. Neospora caninum in free-range chickens of Central Mexico. Vet Parasitol Reg Stud Reports 2016; 5: 31-33. http://dx.doi.org/10.1016/j.vprsr.2016.08.006. PMid:31014534.

Salant H, Mazuz ML, Savitsky I, Nasereddin A, Blinder E, Baneth G. Neospora caninum in crows from Israel. Vet Parasitol 2015; 212(3-4): 375-378. http://dx.doi.org/10.1016/j.vetpar.2015.08.019. PMid:26359640.

Sambrook J, Fritsch EF, Maniatis T. Molecular cloning: a laboratory manual. 2nd ed. New York: Cold Spring Harbor Laboratory Press; 1989.

Sayari M, Namavari M, Mojaver S. Seroprevalence of Neospora caninum infection in free ranging chickens (Gallus domesticus). J Parasit Dis 2016; 40(3): 845-847. http://dx.doi.org/10.1007/s12639-014-0590-8. PMid:27605795.

Silva RC, Machado G. Canine neosporosis: perspectives on pathogenesis and management. Vet Med (Auckl) 2016; 7: 59-70. http:// dx.doi.org/10.2147/VMRR.S76969. PMid:30050838.

Zhang H, Lee E, Yu L, Kawano S, Huang P, Liao M, et al. Identification of the cross-reactive and species-specific antigens between Neospora caninum and Toxoplasma gondii tachyzoites by a proteomics approach. Parasitol Res 2011; 109(3): 899-911. http://dx.doi. org/10.1007/s00436-011-2332-5. PMid:21461729. 